\title{
Leptin-R and its association with PI3K/AKT signaling pathway in papillary thyroid carcinoma
}

\author{
Shahab Uddin ${ }^{1 *}$, Prashant Bavi ${ }^{1 *}$, Abdul K Siraj ${ }^{1 *}$, Maqbool Ahmed ${ }^{1}$, \\ Maha Al-Rasheed ${ }^{1}$, Azhar R Hussain ${ }^{1}$, Mohammed Ahmed ${ }^{2}$, Tarek Amin ${ }^{2}$, \\ Ali Alzahrani ${ }^{2}$, Fouad Al-Dayel ${ }^{3}$, Jehad Abubaker', Rong Bu ${ }^{1}$ \\ and Khawla $S$ Al-Kuraya ${ }^{1}$
}

\begin{abstract}
Departments of ${ }^{1}$ Human Cancer Genomic Research, Research Center, ${ }^{2}$ Endocrinology and ${ }^{3}$ Pathology, King Faisal Specialist Hospital and Research Center, Riyadh, Saudi Arabia

(Correspondence should be addressed to K S Al-Kuraya who is now at Department of Cancer Genomic Research, King Fahad National Center for Children's Cancer and Research, King Faisal Specialist Hospital and Research Cancer, MBC\#98-16, PO Box 3354, Riyadh 11211, Saudi Arabia; Email: kkuraya @kfshrc.edu.sa)

*(S Uddin, P Bavi and A K Siraj contributed equally to this work)
\end{abstract}

\begin{abstract}
The putative role of leptin and its receptor $(\mathrm{Ob}-\mathrm{R})$ in the pathogenesis of various primary human malignancies has been reported; however, their role in papillary thyroid cancer (PTC) has not yet been evaluated. We investigated the role of $\mathrm{Ob}-\mathrm{R}$ in a large tissue microarray cohort of PTC followed by in vitro studies using a panel of PTC cell lines. Ob-R overexpression was seen in $80 \%$ PTCs and was significantly associated with poor disease-free survival $(P=0.0235)$. PTCs that overexpressed Ob-R showed a aggressive phenotype characterized by older age, extrathyroid extension, larger tumor size, nodal metastasis, advanced stage, tall cell variant histological subtype, and a poor disease-free survival $(P=0.0005, P=0.0006, P=0.0398, P=0.0004$, $P=0.0111, P=0.0003$, and $P=0.0235$ respectively). However, Ob-R expression was not an independent prognostic marker to predict disease-free survival in multivariate analysis. PTCs with overexpression of Ob-R showed a significant direct association with overexpression of XIAP $(P<0.0001)$ and $\mathrm{Bcl}-\mathrm{XL}(P<0.0001)$. In vitro analysis showed that leptin stimulated cell proliferation and inhibited apoptosis via activation of phosphatidylinisitol $3^{\prime}$ kinase (PI3K)/protein kinase B (AKT) signaling pathway. Inhibition of PI3K activity by its inhibitor LY294002 abrogated leptin-mediated PI3K/AKT signaling. Gene silencing of Ob-R in PTC cells resulted in downregulation of phospho-AKT, Bcl-XL, and XIAP expression suggesting that leptin-mediated pathogenesis of PTC occurs via involvement of these downstream targets. Altogether, these data show that leptin plays an important role in PTC pathogenesis through PI3K/AKT pathway via Ob-R and is a potential prognostic marker associated with an aggressive phenotype and poor diseasefree survival.
\end{abstract}

Endocrine-Related Cancer (2010) 17 191-202

\section{Introduction}

Papillary thyroid carcinoma (PTC) is the most common malignant thyroid tumor, representing $80-90 \%$ of all thyroid malignancies (Hundahl et al. 1998). The prognosis for PTC is often favorable; however, $\sim 20 \%$ of PTC tumors recur and some reach advanced stages (Loh et al. 1997). Several clinicopathological variables including stage, cancer invasion, and distant metastasis are used for prognostication and treatment selection for PTC (Hay 1990, Siironen et al. 2005). However, the factors and mechanisms determining the aggressive behavior of some papillary carcinomas are not yet completely understood.

Similar to the increasing incidence of thyroid cancer in the United States (Davies \& Welch 2006), incidence of thyroid cancer is also gradually increasing in Saudi 
Arabia (Al-Eid 2004, Khoja 2008). A recent report indicates that there are a fairly high number of Saudi patients with differentiated thyroid cancer who had locally advanced disease at presentation and/or persistent disease after adequate standard treatment (Raef et al. 2008). It is highly improbable that genetic factors alone can explain increase in PTC incidence rate over the past 2 decades, suggesting the role of other environmental factors, including obesity as an etiological factor. So, we believe that population like Saudis, in which dramatic changes in cancer incidence have occurred, may offer a unique opportunity to identify gene environmental interaction. There is a known association between obesity and cancers such as colon cancer (Pan et al. 2004). Many factors including those related to lifestyle may underlie this association, but factors produced by the increased fat mass may be involved. Prevalence of obesity is high in Saudi Arabia among both genders, and the reported incidence is $33.9 \%$ (Al-Othaimeen et al. 2007).

Leptin, the product of obesity gene $(\mathrm{Ob})$, is a $16 \mathrm{kDa}$ adipokine produced predominantly by adipocytes, which regulates food intake and energy expenditure (Janeckova 2001). The adipokine leptin is elevated in the serum of obese people in direct correlation to fat mass (Considine et al. 1996), and may be an important biological link between obesity and various types of cancers. Leptin exerts its activity through specific membrane receptor, the obesity receptor (Ob-R), which is assigned to class I cytokine receptor family (Zabeau et al. 2003). Six splice variants of Ob-R have been identified up to now; a long isoform, four short isoforms discriminated by the different lengths of intracellular domain, and the secreted isoform, which modulates blood leptin (Zabeau et al. 2003, Hegyi et al. 2004). According to the current knowledge, leptin signaling pathway is mainly transduced by Janus activated kinase/signal transducers and activators of transcription (JAK/STAT), mitogen-activated protein kinase (MAPK), and phosphatidylinisitol-3'-kinase (PI3K) signaling pathways (Hegyi et al. 2004). Previously, we have shown that aberrant PI3K/AKT signaling activation plays a role in Middle Eastern PTC pathogenesis (Abubaker et al. 2008b). However, the expression of leptin receptors and the potential correlation between leptin receptors and PI3K/AKT activation have yet to be studied in the Middle Eastern population.

Therefore, in the present study, we assessed the prevalence of leptin receptor (Ob-R), expression, and its correlation with expression patterns of PI3K/AKT pathway proteins as well as other clinicopathological variables in large cohort of Saudi PTC. We further conducted in vitro analysis to examine the expression of leptin receptors using PTC cell lines, and then we investigated the effect of leptin on malignant properties of PTC including proliferation and inhibition of apoptosis.

\section{Materials and methods}

\section{Patient selection and tissue microarray construction}

A total of 536 patients with PTC diagnosed between 1988 and 2004 were selected from King Faisal Specialist Hospital and Research Centre. All PTC and 304 adjacent non neoplastic thyroid tissue were analyzed in a tissue microarray format. Clinical and histopathological data were available for all these patients. Long-term follow-up data were available for most of the patients. Tissue microarrays were constructed from formalin-fixed, paraffin-embedded PTC specimens as previously described (Bavi et al. 2006). Tumor regions were mapped by a pathologist for coring. The tissue microarray was constructed with 0.6- $\mathrm{mm}$ diameter cores spaced $0.8 \mathrm{~mm}$ apart using a modified tissue microarrayer (Beecher Instruments, Sun Prairie, WI, USA). The tissue microarray block was cut into $5 \mathrm{~mm}$ sections, adhered to the slide by an adhesive tape-transfer method (Instrumedics Inc., Hackensack, NJ, USA) and u.v. cross-linked. The Institutional Review Board of the King Faisal Specialist Hospital and Research Centre approved the study.

\section{Immunohistochemistry}

Tissue microarray (TMA) slides were processed and stained manually. The streptavidin-biotin peroxidase technique with diaminobenzidine as chromogen was applied. For antigen retrieval, Dako Target Retrieval Solution, pH 9.0 (catalog number S2368) was used, and the slides were microwaved at $750 \mathrm{~W}$ for $5 \mathrm{~min}$ and then at $250 \mathrm{~W}$ for $30 \mathrm{~min}$. Primary antibodies used, their dilutions, and incidences are listed in Table 1. Endogenous peroxidase activity was quenched using 3\% hydrogen peroxidase. Endogenous biotin was blocked, and all slides were counterstained with hematoxylin, dehydrated, cleared, and cover slipped with premount. Only fresh cut slides were stained simultaneously to minimize the influence of slide aging and maximize repeatability and reproducibility of the experiment. 
Table 1 Antibodies used for tissue microarray immunohistochemical analysis

\begin{tabular}{|c|c|c|c|c|c|c|c|c|}
\hline Antibody & $\begin{array}{l}\text { Positive } \\
\text { cases (\%) }\end{array}$ & Clone & Company & Source & $\begin{array}{l}\text { Dilution } \\
\mathrm{O} / \mathrm{N}^{\mathrm{a}}\end{array}$ & Retrieval & $\begin{array}{l}\text { Subcellular } \\
\text { localization }\end{array}$ & $\begin{array}{l}\text { Detection } \\
\text { system }\end{array}$ \\
\hline Leptin-R & $\begin{array}{l}410 / 512 \\
(80.1 \%)\end{array}$ & B-3 & SCBT & $\begin{array}{l}\text { Mouse } \\
\text { monoclonal }\end{array}$ & $1: 20 \mathrm{O} / \mathrm{N}$ & $\begin{array}{l}\mathrm{pH} 9, \\
\text { pressure } \\
\text { cooker }\end{array}$ & Cytoplasmic & EnVision+ \\
\hline Leptin & $\begin{array}{l}252 / 513 \\
(49.1 \%)\end{array}$ & Y20 & SCBT & $\begin{array}{l}\text { Rabbit } \\
\text { monoclonal }\end{array}$ & $\begin{array}{c}1: 1000 \\
\mathrm{O} / \mathrm{N}\end{array}$ & $\begin{array}{l}\text { pH } 6, \\
\text { pressure } \\
\text { cooker }\end{array}$ & $\begin{array}{l}\text { Nuclear and } \\
\text { cytoplasmic }\end{array}$ & EnVision+ \\
\hline pAKT & $\begin{array}{l}255 / 463 \\
(55.1 \%)\end{array}$ & Ser473 & $\begin{array}{l}\text { Cell } \\
\quad \text { signaling }\end{array}$ & $\begin{array}{l}\text { Rabbit } \\
\text { polyclonal }\end{array}$ & $\begin{array}{l}\text { Predilute } \\
\mathrm{O} / \mathrm{N}\end{array}$ & $\begin{array}{l}\mathrm{pH} 9, \\
\text { microwave }\end{array}$ & $\begin{array}{l}\text { Nuclear and } \\
\text { cytoplasmic }\end{array}$ & $\begin{array}{l}\text { Survival } \\
\text { marker }^{\text {b }}\end{array}$ \\
\hline XIAP & $\begin{array}{l}126 / 505 \\
(24.9 \%)\end{array}$ & 48 & $\begin{array}{l}\mathrm{BD} \\
\quad \text { transduction }\end{array}$ & $\begin{array}{l}\text { Mouse } \\
\text { monoclonal }\end{array}$ & $1: 300 \mathrm{O} / \mathrm{N}$ & $\begin{array}{l}\mathrm{pH} 9, \\
\text { microwave }\end{array}$ & Cytoplasmic & EnVision+ \\
\hline BCLXL & $\begin{array}{l}112 / 514 \\
(21.8 \%)\end{array}$ & $54 \mathrm{H} 6$ & $\begin{array}{l}\text { Cell } \\
\text { signaling }\end{array}$ & $\begin{array}{l}\text { Rabbit } \\
\text { polyclonal }\end{array}$ & $1: 800 \mathrm{O} / \mathrm{N}$ & $\begin{array}{l}\mathrm{pH} 9, \\
\text { microwave }\end{array}$ & Cytoplasmic & EnVision+ \\
\hline PIK3CA & $\begin{array}{l}344 / 503 \\
(68.4 \%)\end{array}$ & $\mathrm{p} 110 \alpha$ & $\begin{array}{l}\text { Cell } \\
\text { signaling }\end{array}$ & $\begin{array}{l}\text { Rabbit } \\
\text { polyclonal }\end{array}$ & $1: 100 \mathrm{O} / \mathrm{N}$ & $\begin{array}{l}\mathrm{pH} 9, \\
\text { pressure } \\
\text { cooker }\end{array}$ & Cytoplasmic & EnVision+ \\
\hline
\end{tabular}

${ }^{a}$ Overnight incubation of primary antibody.

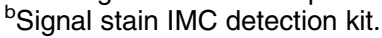

\section{Immunohistochemistry assessment}

Ob-R expression was categorized by doing an $H$ score as previously described (Uddin et al. 2008c). Each TMA spot was assigned an intensity score from 0 to 3 , and proportion of the tumor staining for that intensity was recorded as 5\% increments from a range of 0 to $100(\mathrm{P} 0, \mathrm{P} 1-3)$. A final $H$ score (range 0-300) was obtained by adding the sum of scores obtained for each intensity and proportion of area stained $(H$ score $=\mathrm{I} 1 \mathrm{XP} 1+\mathrm{I} 2 \mathrm{XP} 2+\mathrm{I} 3 \mathrm{XP} 3)$. PTCs were grouped into two groups based on X-tile plots: one with complete absence or reduced staining ( $H$ score $=0-25$ ), and the other group showed over expression $(H$ score $>25)$ depending on the $H$ score. Similarly, X-tile plots were used to stratify the PTC cases into two groups for leptin (Ob), XIAP, and Bcl-XL. p-AKT scoring was done as described earlier (Uddin et al. 2006, Abubaker et al. 2008a). $\mathrm{X}$-tile plots were constructed for assessment of biomarker and optimization of cutoff points based on outcome as has been described earlier (Camp et al. 2004, McCarthy et al. 2005, Badve et al. 2007, Grossman et al. 2007). X-tile plots are created by dividing marker data into three populations: low, middle, and high (i.e. two divisions). We used X-tile version 3.6.1 to define the optimal cutoff point for the overexpression and reduced/absent expression scores for Ob-R. Using this approach, scores of $0-25$ were defined as reduced/absent $\mathrm{Ob}-\mathrm{R}$ expression and 26-300 as Ob-R overexpression.

\section{Statistical analysis}

The JMP7 (SAS Institute, Inc., Cary, NC, USA) software package was used for data analyses. Survival curves were generated using the Kaplan-Meier method, with significance evaluated using the Mantel-Cox log-rank test. Risk ratio was calculated using the Cox proportional hazard model in both univariate and multivariate analyses. The $\chi^{2}$ tests were used to examine relationship between nominal variables. The limit of significance for all analyses was defined as a $P$ value of 0.05 .

\section{Cell culture}

PTC cell lines B-CPAP and 8505C were grown, and maintained as described earlier (Uddin et al. 2008c). Briefly, PTC cell lines were cultured in RPMI 1640 medium supplemented with $10 \%$ ( $\mathrm{vol} / \mathrm{vol})$ fetal bovine serum, $100 \mathrm{U} / \mathrm{ml}$ penicillin, and $100 \mathrm{U} / \mathrm{ml}$ streptomycin at $370{ }^{\circ} \mathrm{C}$ in humidified atmosphere containing $5 \% \mathrm{CO}_{2}$.

\section{Reagents and antibodies}

3-(4,5-dimethylthiazol-2-yl)-2,5-diphenyltetrazolium bromide assays (MTT) was purchased from Sigma. Ob-R antibody was purchased from Abcam (Cambridge, UK). Antibodies against phospho-AKT, phospho-FKHR/FoxO1 antibodies were purchased from Cell Signaling Technologies (Beverly, MA, USA). $\beta$-Actin antibody was purchased from Santa Cruz Biotechnology, Inc. (Santa Cruz, CA, USA). 
Annexin V kit was purchased from Molecular Probes (Eugene, OR, USA). Apoptotic DNA-ladder kit was obtained from Roche.

\section{MTT assays}

Cells $\left(10^{4}\right)$ were incubated in triplicate in a 96-well plate in the presence or absence of indicated test doses of leptin in a final volume of $0.20 \mathrm{ml}$ for $48 \mathrm{~h}$. The ability of leptin to induce cell growth was determined by MTT cell proliferation assays, as previously described (Uddin et al. 2008a). Replicates of six wells for each dosage including vehicle control were analyzed for each experiment.

\section{Annexin V/propidium iodide dual staining}

PTC cell lines were treated with the indicated concentrations of leptin in conditions treated as indicated in figure legends. The cells were harvested, and the percentage of cells undergoing apoptosis was measured by flow cytometry after staining with fluorescein-conjugated annexin $\mathrm{V} /$ propidium iodide as previously described (Hussain et al. 2008).

\section{Cell lysis and immunoblotting}

Cells were treated either with leptin or leptin in combination with PI3K inhibitor LY294002 described in the legends and lysed as previously described (Hussain et al. 2007). Proteins (15-20 $\mu \mathrm{g}$ ) were separated by SDS-PAGE and transferred to polyvinylidene difluoride membrane (Immobilon, Millipore, Billerica, MA, USA). Immunoblotting was done with different antibodies and visualized by enhanced chemiluminescence (Amersham) method.

\section{Gene silencing using small interfering RNA}

Leptin receptor small interfering RNA (siRNA) and scrambled control siRNA were purchased from Qiagen. Cells were transfected using Lipofectamine 2000 (Invitrogen) and siRNA as described earlier (Uddin et al. 2008b). After transfection for $6 \mathrm{~h}$, the lipid and siRNA complex was removed, and fresh growth medium was added and incubated for $48 \mathrm{~h}$. Cells were then treated with leptin as indicated, and after lysis, protein levels were determined by western blot analysis with specific antibodies.

\section{Real-time quantitative PCR}

Total RNA was extracted from PCPAP thyroid cell line after transfection with Ob-R siRNA using TRIzol reagent (Invitrogen). Five microgram of total RNA for each sample was reverse-transcribed in a $20-\mu 1$ reaction volume with SuperScript First-strand Synthesis System (Invitrogen) according to the manufacturer's protocol. The quantitative PCR reaction was performed in glass capillary (Roche) with a final reaction volume of $10 \mu \mathrm{l}$ of $1 \times$ LightCycler-FastStart DNA Master SYBR Green I reaction mixture (Roche) containing FastStart Taq, reaction buffer, and deoxynucleoside triphosphate, $1 \mathrm{mM} \mathrm{MgCl} 2$, and final concentrations of $0.5 \mu \mathrm{M}$ for each primer. For each sample, PCR amplification was performed in duplicate with glyceraldehyde-3phosphate dehydrogenase (GAPDH) used as an endogenous control. The primer sequences for PCR were as follows: OBR-S (sense): $5^{\prime}$-TGATTCTGTGGTGAAGCCACTGC-3' ${ }^{\prime}$, OBR-S (anti-sense): $5^{\prime}$-TTCCATTGTACTTCTTTTCCACTT- $3^{\prime}$ for OBR-S; OBR-L (sense): 5'-AATCACTTCTCCAGAAACGTTTGAGC-3', OBR-L (anti-sense): 5'-AGACCACAGTTGTTGGCATC- $3^{\prime}$ for OBR-L; Bcl-XL (sense): $5^{\prime}$-TTACCTGAATGACCACCTA-3', Bcl-XL (antisense): 5'-ATTTCCGACTGAAGAGTGA-3' for Bcl-XL; XIAP (sense): 5'-GATGCTGTGAGTTCTGATACG-3', XIAP (anti-sense): 3'-CCTAATGTCGAAACTGAAC- $3^{\prime}$ for XIAP; GAPDH (sense): 5'-CCATGGAGAAGGCTGGGG-3', GAPDH (antisense): $5^{\prime}$-CAAAGTTGTCATGGATGACC- $3^{\prime}$ for GAPDH. The relative expression ratio of a target gene is calculated based on efficiency (E) and crossing point (CP) deviation of BCPAP transfected cell line (OBR siRNA) versus control (scrambeled siRNA), and expressed in comparison to a reference gene, GAPDH (Pfaffl et al. 2002, Siraj et al. 2007).

\section{Results}

\section{Immunohistochemical detection of Ob-R expression}

Levels of Ob-R were examined by immunohistochemistry (IHC) in a series of 536 PTC. High levels of Ob-R expression were seen in $80.0 \%$ (410/512) PTC, and in 37.0\% (97/262) adjacent non neoplastic thyroid tissue (Fig. 1). The incidence as well as mean expression levels of Ob-R was higher in PTC (mean $148.73 \pm 107.41)$ as compared to adjacent non neoplastic thyroid tissue $(41.45 \pm 64.14 ; P<0.0001)$. Ob-R expression was significantly higher in the PTC as compared to non neoplastic thyroid tissue (Fig. 2a).

\section{Association of Ob-R with PI3K/AKT pathway proteins}

As shown in Table 2, PTC with Ob-R overexpression showed a significant direct association with PIK3CA $110 \alpha$ protein $($ p110 $\alpha)$ expression $(P<0.0001)$. 

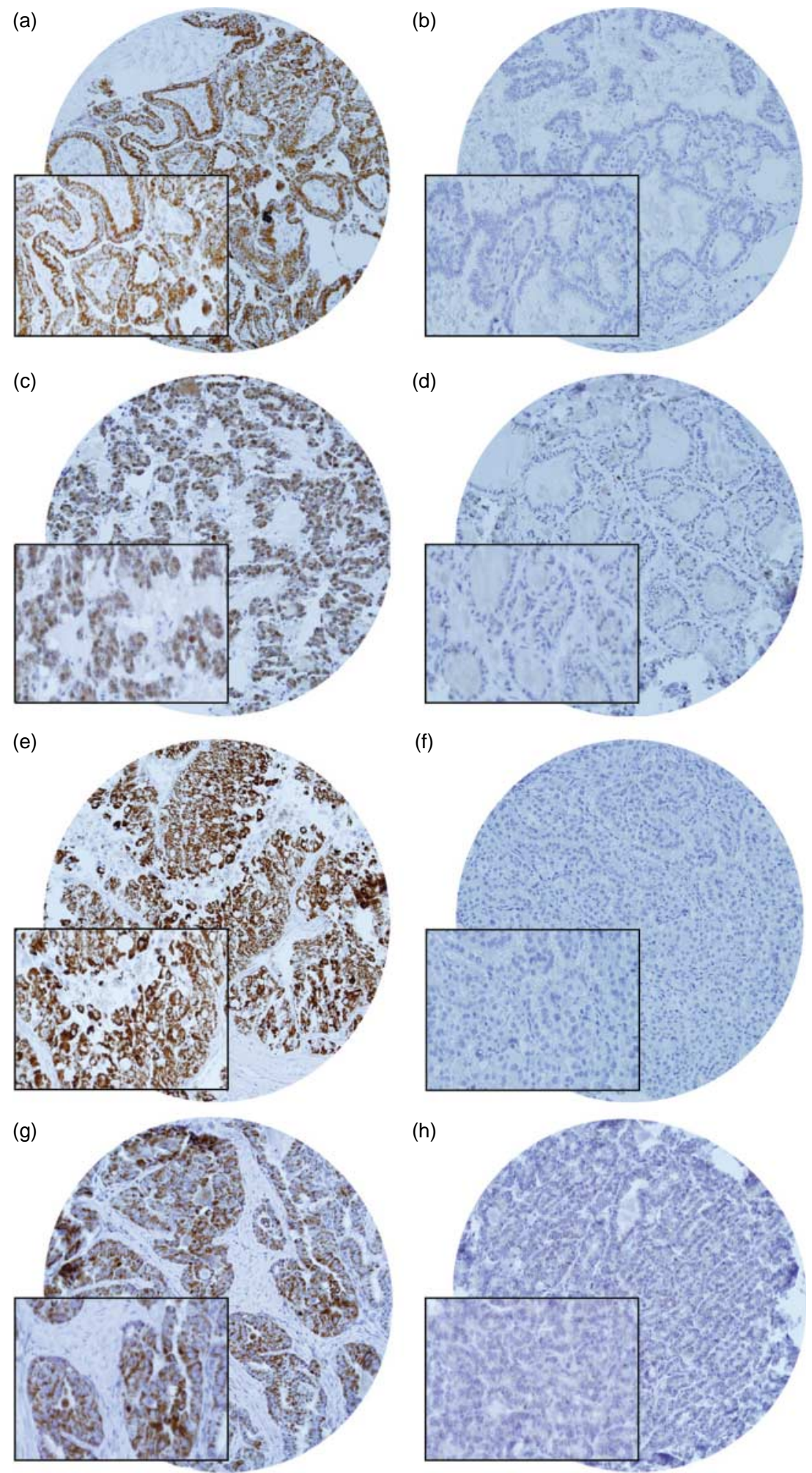

Figure 1 Leptin-R expression in PTC and its association with leptin and downstream anti-apoptotic markers XIAP and Bcl-XL. A PTC tissue microarray spot showing overexpression of (a) leptin-R, (c) leptin, (e) XIAP, and (f) Bcl-XL. Another PTC spot showing low expression of (b) leptin-R, (d) leptin, (f) XIAP, and (g) Bcl-XL. Original magnification $\times 200$ with the inset showing a higher magnification $\times 400$ (immunoperoxidase stain). 

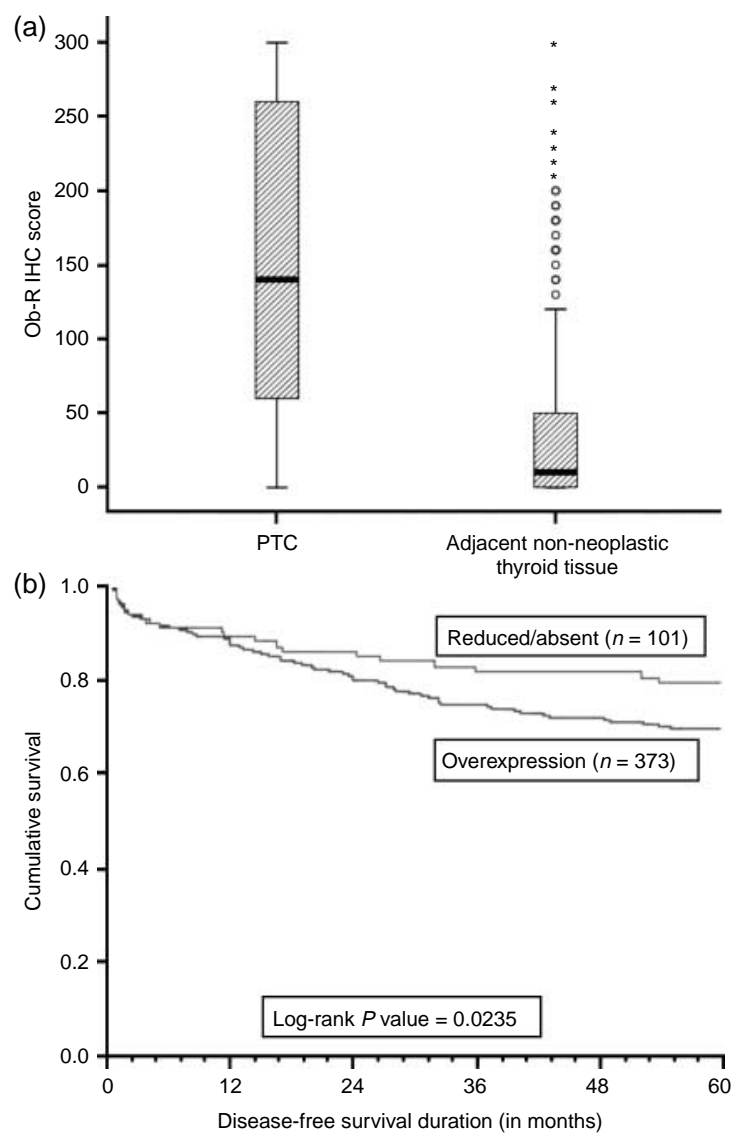

Figure 2 (a) Box plot charts indicate the mean and S.D. of leptin-R expression in two groups - adjacent non neoplastic thyroid tissue and papillary thyroid carcinoma. The expression of Leptin-R in PTC (148.73 \pm 107.41$)$ was significantly higher than adjacent non neoplastic thyroid tissue $(41.45 \pm 64.14$; $P<0.0001$ ). (b) Patients with overexpression of Ob-R had a reduced disease-free survival of $68.9 \%$ at 5 years as compared to $79.3 \%$ with reduced Ob-R expression $(P=0.0235)$.

In addition, PTCs with Ob-R overexpression showed a significant association with downstream targets of PI3K signaling pathway: anti-apoptosis markers XIAP $(P<0.0001)$ and Bcl-XL $(P<0.0001)$.

\section{Ob-R correlation with clinicopathological parameters}

Ob-R expression was correlated with various clinicopathological parameters, and the results are presented in Table 2. PTCs that overexpressed Ob-R showed a aggressive phenotype characterized by older age, extrathyroid extension, larger tumor size, nodal metastasis, advanced stage, and tall cell variant histologic subtype $(P=0.0005, \quad P=0.0006$, $P=0.0398, P=0.0004, P=0.0111$, and $P=0.0003$ respectively).
Patients with reduced Ob-R expression had a better disease-free survival of $79.3 \%$ at 5 years as compared to $68.9 \%$ with overexpression of Ob-R $(P=0.0235$; Fig. 2b). In the multivariate analysis using Cox proportional hazard model for multiple factors like age, gender, extrathyroidal extension, AJCC stage, and Ob-R expression, the relative risk was 1.28 for $\mathrm{Ob}-\mathrm{R}$ overexpression (95\% CI 0.83-1.97; $P=0.2487$ ) and 10.08 for advanced AJCC stage (95\% CI 5.29-19.22; $P \leq 0.0001)$. Thus, Ob-R was not an independent prognostic marker in multivariate analysis (Table 3 ).

\section{Leptin increase proliferation of PTC cells}

The effects of leptin on growth rate of PTC cell lines were determined using MTT assay. 8505C and B-CPAP cells were initially serum starved for $24 \mathrm{~h}$ and then stimulated with various doses of recombinant leptin (10-200 ng/ml) for $48 \mathrm{~h}$ and compared to cell serum-free control cultures. As shown in Fig. 3a, leptin induced significant cell growth of both PTC cell lines in a dose-dependent manner.

\section{Leptin prevent serum-starved apoptosis in PTC cells}

PTC cell lines were seeded in six-well plates, and after $24 \mathrm{~h}$, serum-free medium alone or $100 \mathrm{ng} / \mathrm{ml}$ leptin was added. After $48 \mathrm{~h}$, apoptosis was measured by annexin/PI staining. As shown in Fig. 3b, serum starvation resulted in apoptosis. Treatment of PTC cell line with leptin significantly prevented serum-starved apoptosis demonstrating that leptin counteracts apoptosis in PTC cells $(P=0.0005)$.

\section{Leptin activates the PI3K/AKT signaling pathway}

PI3K pathways have been implicated in playing crucial roles in regulating cell growth, cell proliferation, and prevention of apoptosis, which altogether attribute tumorigenesis (Osaki et al. 2004). In view of these findings, we sought to determine whether PI3K signaling is activated during leptin stimulated PTC cell line proliferation. B-CPAP cells were stimulated with $100 \mathrm{ng} / \mathrm{ml}$ leptin for various time periods. Cells were lysed, and proteins were separated on SDS-PAGE and immunoblotted with p-AKT (activated AKT) and p-FOXO1 antibodies. As shown in Fig. 4a, leptin treatment of B-CPAP phosphorylated AKT and FOXO1 as early as $15 \mathrm{~min}$ and remained phosphorylated till $3 \mathrm{~h}$. Similar results were obtained with other PTC cell lines (data not shown). These results show that leptin-mediated cell proliferation occurs via PI3K/AKT signaling pathway. 
Table 2 Clinical characteristics and Ob-R in papillary thyroid cancer (PTC)

\begin{tabular}{|c|c|c|c|c|c|c|c|}
\hline & \multicolumn{2}{|c|}{ Total } & \multicolumn{2}{|c|}{ Ob-R overexpression } & \multicolumn{2}{|c|}{ Low Ob-R expression } & \multirow[b]{2}{*}{$P$ value } \\
\hline & No. & $\%$ & No. & $\%$ & No. & $\%$ & \\
\hline No. of patients & 512 & & 410 & 80.1 & 102 & 19.9 & \\
\hline \multicolumn{8}{|l|}{ Age (years) } \\
\hline$\leq 45$ & 306 & 59.8 & 230 & 75.2 & 73 & 24.8 & 0.0005 \\
\hline$>45$ & 206 & 40.2 & 180 & 87.4 & 26 & 12.6 & \\
\hline \multicolumn{8}{|l|}{ Sex } \\
\hline Female & 371 & 72.5 & 292 & 78.7 & 79 & 21.3 & 0.2003 \\
\hline Male & 141 & 27.5 & 118 & 83.7 & 23 & 16.3 & \\
\hline \multicolumn{8}{|c|}{ Extrathyroidal extension } \\
\hline Absent & 254 & 49.6 & 188 & 74.0 & 66 & 26.0 & 0.0006 \\
\hline Present & 258 & 50.4 & 222 & 86.0 & 36 & 14.0 & \\
\hline \multicolumn{8}{|l|}{ pT } \\
\hline pT1 & 141 & 28.2 & 104 & 73.8 & 37 & 26.2 & 0.0398 \\
\hline рT2 & 90 & 18.0 & 71 & 78.9 & 19 & 21.1 & \\
\hline рT3 & 254 & 50.8 & 214 & 84.2 & 40 & 15.8 & \\
\hline pT4 & 15 & 3.0 & 14 & 93.3 & 1 & 6.7 & \\
\hline \multicolumn{8}{|l|}{$\mathrm{pN}$} \\
\hline pNO & 176 & 37.1 & 126 & 71.6 & 50 & 28.4 & 0.0004 \\
\hline $\mathrm{pN} 1$ & 298 & 62.9 & 254 & 85.2 & 44 & 14.8 & \\
\hline \multicolumn{8}{|l|}{$\mathrm{pM}$} \\
\hline pM0 & 445 & 89.5 & 357 & 80.2 & 88 & 19.8 & 0.5799 \\
\hline pM1 & 52 & 10.5 & 40 & 76.9 & 12 & 23.1 & \\
\hline \multicolumn{8}{|l|}{ Stage } \\
\hline 1 & 288 & 60.4 & 220 & 76.4 & 68 & 23.6 & 0.0111 \\
\hline II & 34 & 7.1 & 25 & 73.5 & 9 & 26.5 & \\
\hline III & 35 & 7.3 & 30 & 85.7 & 5 & 14.3 & \\
\hline IV & 120 & 25.2 & 107 & 89.2 & 13 & 10.8 & \\
\hline \multicolumn{8}{|l|}{ Histology type } \\
\hline Follicular variant & 65 & 12.7 & 39 & 60.0 & 26 & 40.0 & 0.0003 \\
\hline Papillary-classical & 428 & 83.6 & 355 & 82.9 & 73 & 17.1 & \\
\hline Tall cell variant & 19 & 3.7 & 16 & 84.2 & 3 & 15.8 & \\
\hline \multicolumn{8}{|l|}{ Surgical margins } \\
\hline Positive & 73 & 38.6 & 64 & 87.7 & 9 & 12.3 & 0.4407 \\
\hline Negative & 116 & 61.4 & 97 & 83.6 & 19 & 16.4 & \\
\hline \multicolumn{8}{|l|}{ OB-Y20 } \\
\hline Any one high & 250 & 49.6 & 218 & 87.2 & 32 & 12.8 & 0.0004 \\
\hline Both low & 254 & 50.4 & 190 & 74.8 & 64 & 25.2 & \\
\hline \multicolumn{8}{|l|}{$\mathrm{p}-\mathrm{AKT}$} \\
\hline High (2-3) & 245 & 54.3 & 202 & 82.4 & 43 & 17.6 & 0.5232 \\
\hline Low $(0-1)$ & 206 & 45.7 & 165 & 80.1 & 41 & 19.9 & \\
\hline \multicolumn{8}{|l|}{ XIAP } \\
\hline Above 120 & 126 & 25.4 & 124 & 98.4 & 2 & 1.6 & $<0.0001$ \\
\hline Below $=120$ & 370 & 74.6 & 278 & 75.1 & 92 & 24.9 & \\
\hline \multicolumn{8}{|l|}{ BCLXL } \\
\hline Above 270 & 112 & 22.2 & 109 & 97.3 & 3 & 2.7 & $<0.0001$ \\
\hline Below $=270$ & 392 & 77.8 & 300 & 76.5 & 92 & 23.5 & \\
\hline \multicolumn{8}{|l|}{ PIK3CA } \\
\hline Above 170 & 340 & 69.0 & 301 & 88.5 & 39 & 11.5 & $<0.0001$ \\
\hline Below $=170$ & 153 & 31.0 & 97 & 63.4 & 56 & 36.6 & \\
\hline
\end{tabular}


Table 3 Distribution of Leptin-R in papillary thyroid carcinoma by Cox model analysis

\begin{tabular}{|c|c|c|c|c|}
\hline \multirow[b]{2}{*}{ Clinical parameters } & \multicolumn{2}{|c|}{ Univariate } & \multicolumn{2}{|c|}{ Multivariate } \\
\hline & Risk ratio $(95 \% \mathrm{Cl})$ & $P$ value & Risk ratio $(95 \% \mathrm{Cl})$ & $P$ value \\
\hline Age above $=45$ & 2.60 (1.93-3.49) & $<0.0001$ & $0.34(0.18-0.65)$ & 0.0014 \\
\hline Sex male & $1.36(0.98-1.87)$ & 0.0624 & $1.21(0.86-1.70)$ & 0.2719 \\
\hline ET: present ${ }^{\mathrm{a}}$ & 2.07 (1.53-2.82) & $<0.0001$ & $1.25(0.88-1.77)$ & 0.2081 \\
\hline Advanced stage & 4.41 (3.23-6.06) & $<0.0001$ & $10.11(5.19-18.84)$ & $<0.0001$ \\
\hline Histology & 1.59 (0.75-2.93) & 0.2065 & $1.38(0.62-2.63)$ & 0.3994 \\
\hline Leptin-R high & $1.58(1.08-2.40)$ & 0.0184 & $1.28(0.84-2.01)$ & 0.2494 \\
\hline
\end{tabular}

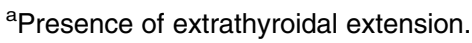

\section{Inhibition of PI3K prevents leptin-mediated AKT activation and its downstream effector FOXO1}

Since our study has demonstrated that leptin stimulated PI3K signaling plays a role in PTC proliferation and promotes its anti-apoptotic effects, we sought to determine whether the inhibition of PI3K by its specific inhibitor, LY294002, abrogated leptin-mediated PI3K/AKT signaling in PTC cell lines. Cells were seeded on culture plates for $24 \mathrm{~h}$. Starved PTC cell were pretreated with $20 \mu \mathrm{M}$ LY294002 for $2 \mathrm{~h}$, and subsequently treated with and without $100 \mathrm{ng} / \mathrm{ml}$ leptin for $3 \mathrm{~h}$. Cells were
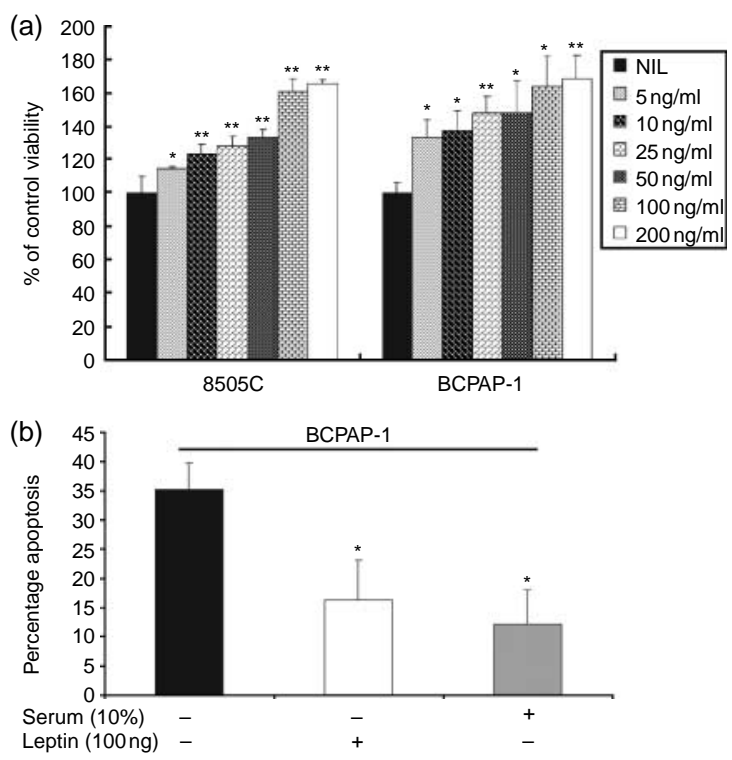

Figure 3 Leptin increases proliferation of PTC cells and prevents serum-starved apoptosis in PTC cells. (a) PTC cell lines were seeded in 96-well plates, and after $24 \mathrm{~h}$, serum-free medium alone or with various doses of leptin as indicated was added. After $48 \mathrm{~h}$, cell proliferation was measured MTT as described in Materials and methods. The graph displays the mean \pm s.D. of six independent experiments. (b) PTC cell lines were seeded in six-well plates, and after $24 \mathrm{~h}$, serum-free medium alone or $100 \mathrm{ng} / \mathrm{ml}$ was added. After $48 \mathrm{~h}$, apoptosis was measured by annexin/PI staining. lysed, and proteins were separated on SDS-PAGE and immunoblotted by antibodies against p-AKT and p-FOXO1. As shown in Fig. 4b, leptin phosphorylated AKT and FOXO1 in B-CPAP PTC cell line and pretreatment with LY294002, prevented AKT and FOXO1 phosphorylation suggesting that PI3K/AKT pathway plays a critical role in leptin-induced growth and proliferation of PTC cells. These data clearly demonstrate that leptin is acting upstream of PI3K/AKT pathway in modulating its anti-apoptotic response in PTC cells.

\section{PTC cell lines express leptin receptors that mediate the PI3K/AKT signaling pathways}

To investigate whether leptin receptors are functional and linked to coordinate with PI3K/AKT signaling pathway to regulate cell growth and proliferation of PTC cell lines, we utilized siRNA strategies to transfect Ob-R specific siRNA as well as scrambled non specific siRNA in B-CPAP cell line. After $48 \mathrm{~h}$ transfection, cell were starved and then treated with and without $100 \mathrm{ng} / \mathrm{ml}$ leptin for $3 \mathrm{~h}$. As shown in Fig. 5a, B-CPAP expressed functional leptin receptors, as previously shown (Hardwick et al. 2001). Treatment of scrambled siRNA harboring B-CPAP cells with leptin showed activation of AKT, FOXO1, and elevated level of XIAP and Bcl-XL proteins that are involved in PI3K/AKT pathway and play a critical role in cell survival. On the other hand, expression of Ob-R specific siRNA in B-CPAP cells knocked down the expression of leptin receptor and prevented leptininduced activation of AKT, FOXO1 as well as abrogated the expression of XIAP and Bcl-XL proteins. Gene silencing of $\mathrm{Ob}-\mathrm{R}$ in B-CPAP cells downregulated $\mathrm{Bcl}-\mathrm{XL}$ and XIAP at the transcription level (Fig. 5b). These data suggest that leptin utilizes PI3K/AKT signal transduction pathway in mediation of PTC cell proliferation, further confirming that leptin is acting upstream of PI3K/AKT pathway. 
(a)

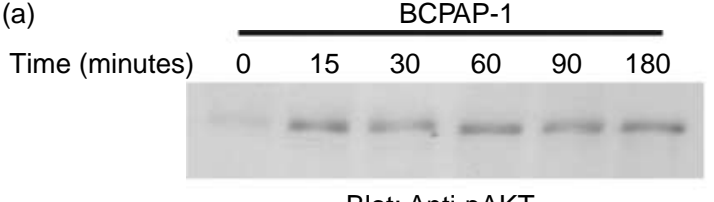

Blot: Anti-pAKT

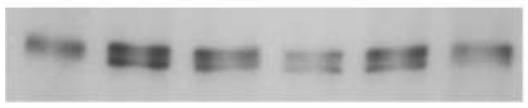

Blot: Anti-pFOXO1

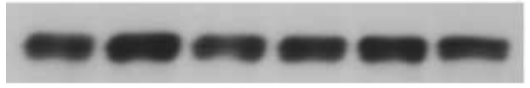

Blot: Anti- $\beta$-actin

(b)
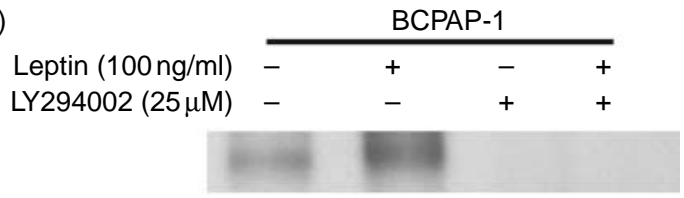

Blot: Anti-pAKT

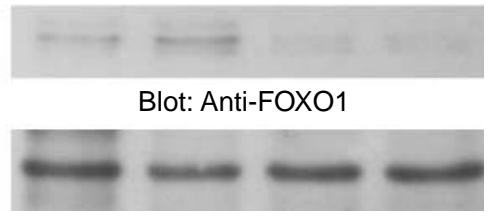

Blot: Anti- $\beta$-actin

Figure 4 Leptin activates PI3-kinase/AKT signaling pathway. (a) BCPAP cells were serum starved for $24 \mathrm{~h}$ in serum-free medium, followed by stimulation with recombinant leptin $(100 \mathrm{ng} / \mathrm{ml})$ for various time periods as indicated. After cell lysis, $20 \mu \mathrm{g}$ proteins were separated by SDS-PAGE, transferred to immobilon membrane, and immunoblotted with antibodies against p-AKT-Ser 473, FOXO1, and $\beta$-actin. (b) LY294002 inhibitor abrogated leptin-induced anti-apoptosis PI3-kinase/ AKT signaling in PTC. B-CPAP cells were serum starved for $24 \mathrm{~h}$, and then cells were pretreated with $20 \mu \mathrm{M}$ LY294002 for $2 \mathrm{~h}$ and subsequently stimulated with recombinant leptin $(100 \mathrm{ng} / \mathrm{ml})$ for $15 \mathrm{~min}$; proteins were separated by SDS-PAGE, transferred to immobilon membrane, and immunoblotted with antibodies against p-AKT-Ser 473, FOXO1, and $\beta$-actin.

\section{Discussion}

Recent reports show that leptin is overexpressed in various cancer cells and plays a role in the development and/or progression of variety of malignancies including colon, gastric, endometrial, and breast cancers (Hu et al. 2002, Ishikawa et al. 2004, Hong et al. 2006, Koda et al. 2007a,b). These findings were further supported by experimental evidence that leptin can stimulate growth and prevent apoptosis in different cellular cancer models (Garofalo \& Surmacz 2006, Hoda et al. 2007, Ogunwobi \& Beales 2007). Earlier reports have highlighted that leptin might have an important role in thyroid pathophysiology due to thyroid hormone involvement in thermogenesis, regulation of uncoupling proteins, and leptin levels are significantly higher in hypothyroid patients (Leonhardt et al. 1998, Zimmermann-Belsing et al. 2003).

However, the potential role of leptin/Ob-R in the pathogenesis of PTC has not been elucidated. In the current study, therefore, we examined the prevalence of leptin and its receptor Ob-R expression in 536 Saudi PTC samples. Our data show that Ob-R protein expression was detected in $80 \%$ PTC. Interestingly, Ob-R was significantly associated with older age, extrathyroid extension, larger tumor size, nodal metastasis, advanced stage, and tall cell variant histologic subtype, thereby indicating that Ob-R overexpression identifies an aggressive phenotype of Middle Eastern PTC. Furthermore, patients with high Ob-R-expressing tumors showed a significant poor disease-free survival $(P<0.0235)$ as compared with

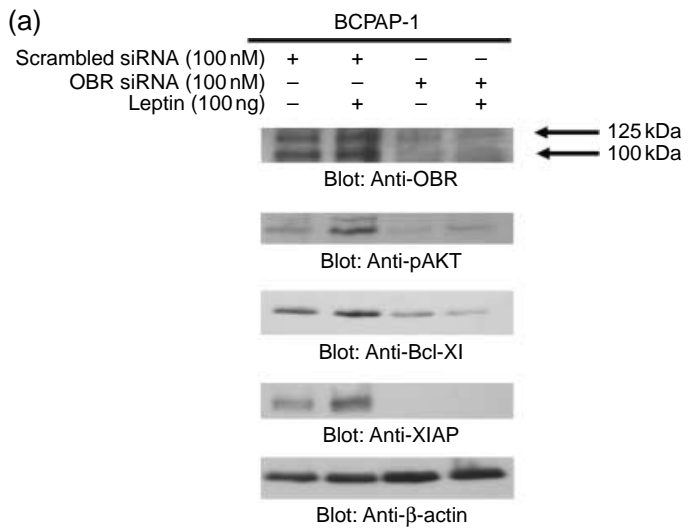

(b)

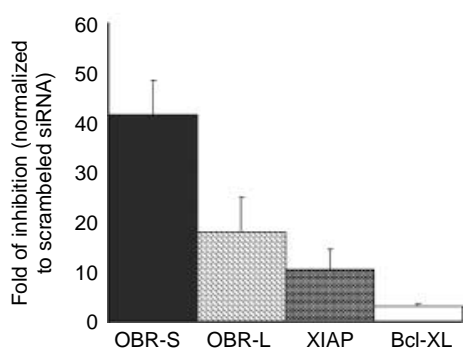

Figure 5 Leptin required functional leptin receptor (Ob-R) for activation of PI3-kinase/AKT signaling in PTC cell lines. (a) B-CPAP cells were transfected with scrambled siRNA and leptin receptor siRNA (50 and $100 \mathrm{nM}$ ) with Lipofectamine. After $48 \mathrm{~h}$, cells were starved and treated with $100 \mathrm{ng} / \mathrm{ml}$ for $3 \mathrm{~h}$, and proteins were immunoblotted with antibodies against leptin receptor, p-AKT-Ser473, FOXO1, Bcl-XL, XIAP, and $\beta$-actin. (b) B-CPAP cells were transfected with scrambled siRNA and leptin receptor siRNA (100 nM) with Lipofectamine in six-well plates. After $48 \mathrm{~h}$, total RNA was isolated. RT-PCR analysis of $\mathrm{ObR}-\mathrm{L}, \mathrm{ObR}-\mathrm{S}, \mathrm{XIAP}$, and $\mathrm{Bcl}-\mathrm{XL}$ was performed. The relative expression (fold of inhibition) of Ob-R, XIAP, and Bcl-XL analyzed by real-time PCR was normalized to GAPDH. $P<0.01$ versus scrambled control; mean \pm s.E.M.; $n=6$. 
reduced Ob-R expression. Raef et al. (2008) have reported a fairly high number of patients with differentiated thyroid cancer (DTC) in Saudi Arabia who had locally advanced disease at presentation and/ or persistent disease after standard treatment (Raef et al. 2008). It is tempting to speculate that high $\mathrm{Ob}-\mathrm{R}$ expression levels seen in around $80 \%$ of the Saudi Arabian PTCs could be one of the putative factors for this disease persistence and/or recurrence. Leptin-R along with a panel of other markers could be used to develop an algorithm to prognosticate PTC patients on fine needle aspiration biopsy (FNAB) or other presurgical screening assays. This would be quite similar to the recently reported use of leptin along with IL6 as key early markers of the metabolic alterations and symptoms associated with disease progression in advanced stage ovarian cancer (Maccio et al. 2008, Kim et al. 2009). The use of Ob-R as a panel of prognostic marker in thyroid cancer is yet only an attractive hypothesis and needs to be confirmed by similar such studies in different cohorts.

Interaction between leptin/Ob-R and other signaling pathway such as PI3K/AKT in oncogenesis has been reported in other solid tumors previously (Chen et al. 2006, Ogunwobi et al. 2006, Sharma et al. 2006, Hoda et al. 2007, Saxena et al. 2007). Therefore, we examined the relationship between the expression of $\mathrm{Ob}-\mathrm{R}$ and the PI3K/AKT pathway protein targets in PTC. Activated AKT (pAKT) protein expression was seen in 55\% of our PTC examined. However, no correlation was observed with $\mathrm{Ob}-\mathrm{R}$ expression and AKT activation by IHC staining, which might suggest the presence of other upstream signaling pathways can also be involved in the activation of AKT. However, Ob-R overexpression was correlated with upstream marker PIK3CA $110 \alpha$ protein expression $(P<0.0001)$ and other downstream targets of PI3K/AKT, the antiapoptotic markers Bcl-XL and XIAP $(P<0.0001$ and $<0.0001$ respectively).

After documenting the high prevalence of $\mathrm{Ob}-\mathrm{R}$ in Saudi PTC, we sought to conduct in vitro analysis to elucidate the molecular mechanism by which leptin exerts its oncogenic action on PTC and its relation with PI3K/AKT signaling pathway. Using PTC cell lines, we investigated the oncogenic effect of leptin on PTC cells, and this oncogenic effect is due to a combination of cell proliferation and inhibition of apoptosis by leptin. Our in vitro experiments clearly showed that leptin rapidly stimulates the PI3K pathway and induced the phosphorylation of AKT, thus activating of this key signal transduction pathway associated with cell growth. In addition, prevention of leptin-induced activation of PI3K with chemical inhibitors in turn significantly reduced the activation of AKT pathway. AKT provides a survival signal protecting cells from apoptosis induced by various stresses by multiple mechanisms such as phosphorylation of Bad, GSK3, FOXO transcription factors, and caspase 9 (Datta et al. 1997, Brunet et al. 2001). Phosphorylation of these proteins results in inactivation of their apoptotic functions. As shown in our study, AKT phosphorylation was increased in leptintreated human PTC cells, and inhibition of PI3K with LY294002 abolished leptin-induced proliferation. Thus, we can hypothesize that leptin mediates its actions upstream of PI3K.

In summary, our data for the first time deciphered the molecular mechanisms responsible for the leptinmediated PTC cell proliferation, establishing direct link between leptin and PTC carcinogenesis through $\mathrm{PI} 3 \mathrm{~K} / \mathrm{AKT}$ signaling pathway. Ob-R expression is seen in majority of the PTC, and OB-R could be a panel of biomarkers with potential prognostic utility.

\section{Declaration of interest}

The authors declare that there is no conflict of interest that could be perceived as prejudicing the impartiality of the research reported.

\section{Funding}

This research did not receive any specific grant from any funding agency in the public, commercial, or not-for-profit sector.

\section{Acknowledgements}

The authors thanks Mehar Sultana, Valerie Atizado Thara George, and Valorie Balde for their technical assistance; Zeeshan Qadri and Sriraman Devarajan for data abstraction and statistical analysis.

\section{References}

Abubaker J, Bavi P, Al-Harbi S, Ibrahim M, Siraj AK, Al-Sanea N, Abduljabbar A, Ashari LH, Alhomoud S, Al-Dayel F et al. 2008a Clinicopathological analysis of colorectal cancers with PIK3CA mutations in Middle Eastern population. Oncogene 27 3539-3545.

Abubaker J, Jehan Z, Bavi P, Sultana M, Al-Harbi S, Ibrahim M, Al-Nuaim A, Ahmed M, Amin T, Al-Fehaily M et al. $2008 b$ Clinicopathological analysis of papillary thyroid cancer with PIK3CA alterations in a Middle Eastern population. Journal of Clinical Endocrinology and Metabolism 93 611-618.

Al-Eid HS AS 2004 Cancer Incidence Report Saudi Arabia 1999-2000. King Faisal Specialist Hospital and Research Centre. May 2004. 
Al-Othaimeen AI, Al-Nozha M \& Osman AK 2007 Obesity: an emerging problem in Saudi Arabia. Analysis of data from the National Nutrition Survey. Eastern Mediterranean Health Journal 13 441-448.

Badve S, Turbin D, Thorat MA, Morimiya A, Nielsen TO, Perou CM, Dunn S, Huntsman DG \& Nakshatri H 2007 FOXA1 expression in breast cancer - correlation with luminal subtype A and survival. Clinical Cancer Research 13 4415-4421.

Bavi P, Jehan Z, Atizado V, Al-Dossari H, Al-Dayel F, Tulbah A, Amr SS, Sheikh SS, Ezzat A, El-Solh H et al. 2006 Prevalence of fragile histidine triad expression in tumors from Saudi Arabia: a tissue microarray analysis. Cancer Epidemiology, Biomarkers \& Prevention 15 1708-1718.

Brunet A, Park J, Tran H, Hu LS, Hemmings BA \& Greenberg ME 2001 Protein kinase SGK mediates survival signals by phosphorylating the forkhead transcription factor FKHRL1 (FOXO3a). Molecular and Cellular Biology 21 952-965.

Camp RL, Dolled-Filhart M \& Rimm DL 2004 X-tile: a new bio-informatics tool for biomarker assessment and outcome-based cut-point optimization. Clinical Cancer Research 10 7252-7259.

Chen C, Chang YC, Liu CL, Chang KJ \& Guo IC 2006 Leptin-induced growth of human ZR-75-1 breast cancer cells is associated with up-regulation of cyclin D1 and c-Myc and down-regulation of tumor suppressor p53 and p21WAF1/CIP1. Breast Cancer Research and Treatment 98 121-132.

Considine RV, Sinha MK, Heiman ML, Kriauciunas A, Stephens TW, Nyce MR, Ohannesian JP, Marco CC, McKee LJ, Bauer TL et al. 1996 Serum immunoreactiveleptin concentrations in normal-weight and obese humans. New England Journal of Medicine 334 292-295.

Datta SR, Dudek H, Tao X, Masters S, Fu H, Gotoh Y \& Greenberg ME 1997 Akt phosphorylation of BAD couples survival signals to the cell-intrinsic death machinery. Cell 91 231-241.

Davies L \& Welch HG 2006 Increasing incidence of thyroid cancer in the United States, 1973-2002. Journal of the American Medical Association 295 2164-2167.

Garofalo C \& Surmacz E 2006 Leptin and cancer. Journal of Cellular Physiology 207 12-22.

Grossman SR, Lyle S, Resnick MB, Sabo E, Lis RT, Rosinha E, Liu Q, Hsieh CC, Bhat G, Frackelton AR Jr et al. 2007 p66 Shc tumor levels show a strong prognostic correlation with disease outcome in stage IIA colon cancer. Clinical Cancer Research 13 5798-5804.

Hardwick JC, Van Den Brink GR, Offerhaus GJ, Van Deventer SJ \& Peppelenbosch MP 2001 Leptin is a growth factor for colonic epithelial cells. Gastroenterology 121 79-90.

Hay ID 1990 Papillary thyroid carcinoma. Endocrinology and Metabolism Clinics of North America 19 545-576.

Hegyi K, Fulop K, Kovacs K, Toth S \& Falus A 2004 Leptininduced signal transduction pathways. Cell Biology International 28 159-169.
Hoda MR, Keely SJ, Bertelsen LS, Junger WG, Dharmasena D \& Barrett KE 2007 Leptin acts as a mitogenic and antiapoptotic factor for colonic cancer cells. British Journal of Surgery 94 346-354.

Hong SJ, Kwon KW, Kim SG, Ko BM, Ryu CB, Kim YS, Moon JH, Cho JY, Lee JS, Lee MS et al. 2006 Variation in expression of gastric leptin according to differentiation and growth pattern in gastric adenocarcinoma. Cytokine 33 66-71.

Hu X, Juneja SC, Maihle NJ \& Cleary MP 2002 Leptin - a growth factor in normal and malignant breast cells and for normal mammary gland development. Journal of the National Cancer Institute 94 1704-1711.

Hundahl SA, Fleming ID, Fremgen AM \& Menck HR 1998 A National Cancer Data Base report on 53,856 cases of thyroid carcinoma treated in the U.S., 1985-1995 (see commetns). Cancer 83 2638-2648.

Hussain AR, Al-Jomah NA, Siraj AK, Manogaran P, Al-Hussein K, Abubaker J, Platanias LC, Al-Kuraya KS \& Uddin S 2007 Sanguinarine-dependent induction of apoptosis in primary effusion lymphoma cells. Cancer Research 67 3888-3897.

Hussain AR, Ahmed M, Al-Jomah NA, Khan AS, Manogaran P, Sultana M, Abubaker J, Platanias LC, Al-Kuraya KS \& Uddin S 2008 Curcumin suppresses constitutive activation of nuclear factor-kappa B and requires functional Bax to induce apoptosis in Burkitt's lymphoma cell lines. Molecular Cancer Therapeutics 7 3318-3329.

Ishikawa M, Kitayama J \& Nagawa H 2004 Enhanced expression of leptin and leptin receptor (OB-R) in human breast cancer. Clinical Cancer Research $\mathbf{1 0}$ 4325-4331.

Janeckova R 2001 The role of leptin in human physiology and pathophysiology. Physiological Research 50 443-459.

Khoja TAM 2008 Cancer Incidence Among Gulf Cooperation Council States Nationals-2003, edn 2006, pp 37-44. Eds Gulf Center for Cancer Registration. Riyadh, Saudi Arabia: King Faisal Specialist Hospital \& Research Centre.

Kim K, Visintin I, Alvero AB \& Mor G 2009 Development and validation of a protein-based signature for the detection of ovarian cancer. Clinics in Laboratory Medicine 29 47-55.

Koda M, Sulkowska M, Kanczuga-Koda L, Surmacz E \& Sulkowski S 2007a Overexpression of the obesity hormone leptin in human colorectal cancer. Journal of Clinical Pathology 60 902-906.

Koda M, Sulkowska M, Wincewicz A, Kanczuga-Koda L, Musiatowicz B, Szymanska M \& Sulkowski S 2007b Expression of leptin, leptin receptor, and hypoxiainducible factor 1 alpha in human endometrial cancer. Annals of the New York Academy of Sciences 1095 90-98.

Leonhardt U, Ritzel U, Schafer G, Becker W \& Ramadori G 1998 Serum leptin levels in hypo- and hyperthyroidism. Journal of Endocrinology 157 75-79. 
Loh KC, Greenspan FS, Gee L, Miller TR \& Yeo PP 1997 Pathological tumor-node-metastasis (pTNM) staging for papillary and follicular thyroid carcinomas: a retrospective analysis of 700 patients. Journal of Clinical Endocrinology and Metabolism 82 3553-3562.

Maccio A, Madeddu C, Massa D, Astara G, Farci D, Melis GB \& Mantovani G 2008 Interleukin-6 and leptin as markers of energy metabolic changes in advanced ovarian cancer patients. Journal of Cellular and Molecular Medicine [in press].

McCarthy MM, Sznol M, DiVito KA, Camp RL, Rimm DL \& Kluger HM 2005 Evaluating the expression and prognostic value of TRAIL-R1 and TRAIL-R2 in breast cancer. Clinical Cancer Research 11 5188-5194.

Ogunwobi OO \& Beales IL 2007 The anti-apoptotic and growth stimulatory actions of leptin in human colon cancer cells involves activation of JNK mitogen activated protein kinase, JAK2 and PI3 kinase/Akt. International Journal of Colorectal Disease 22 401-409.

Ogunwobi O, Mutungi G \& Beales IL 2006 Leptin stimulates proliferation and inhibits apoptosis in Barrett's esophageal adenocarcinoma cells by cyclooxygenase-2-dependent, prostaglandin- $\mathrm{E}_{2}$-mediated transactivation of the epidermal growth factor receptor and c-Jun $\mathrm{NH}_{2}$-terminal kinase activation. Endocrinology 147 4505-4516.

Osaki M, Oshimura M \& Ito H 2004 PI3K-Akt pathway: its functions and alterations in human cancer. Apoptosis 9 667-676.

Pan SY, Johnson KC, Ugnat AM, Wen SW \& Mao Y 2004 Association of obesity and cancer risk in Canada. American Journal of Epidemiology 159 259-268.

Pfaffl MW, Georgieva TM, Georgiev IP, Ontsouka E, Hageleit M \& Blum JW 2002 Real-time RT-PCR quantification of insulin-like growth factor (IGF)-1, IGF-1 receptor, IGF-2, IGF-2 receptor, insulin receptor, growth hormone receptor, IGF-binding proteins 1, 2 and 3 in the bovine species. Domestic Animal Endocrinology 22 91-102.

Raef H, Alfadhli E, Al-Hajjaj A, Malabu UH, Al-Sobhi S, Rifai A \& Al Nuaim A 2008 High rate of persistent/recurrent disease among patients with differentiated thyroid cancer in Saudi Arabia: factors affecting nonremission. Annals of Saudi Medicine 28 277-281.

Saxena NK, Sharma D, Ding X, Lin S, Marra F, Merlin D \& Anania FA 2007 Concomitant activation of the JAK/STAT, PI3K/AKT, and ERK signaling is involved in leptin-mediated promotion of invasion and migration of hepatocellular carcinoma cells. Cancer Research 67 2497-2507.

Sharma D, Saxena NK, Vertino PM \& Anania FA 2006 Leptin promotes the proliferative response and invasiveness in human endometrial cancer cells by activating multiple signal-transduction pathways. EndocrineRelated Cancer 13 629-640.

Siironen P, Louhimo J, Nordling S, Ristimaki A, Maenpaa H, Haapiainen R \& Haglund C 2005 Prognostic factors in papillary thyroid cancer: an evaluation of 601 consecutive patients. Tumour Biology 26 57-64.

Siraj A, Bavi P, Abubaker J, Jehan Z, Sultana M, Al-Dayel F, Al-Nuaim A, Alzahrani A, Ahmed M, Al-Sanea O et al. 2007 Genome-wide expression analysis of Middle Eastern papillary thyroid cancer reveals c-MET as a novel target for cancer therapy. Journal of Pathology 213 190-199.

Uddin S, Hussain AR, Siraj AK, Manogaran PS, Al-Jomah NA, Moorji A, Atizado V, Al-Dayel F, Belgaumi A, El-Solh H et al. 2006 Role of phosphatidylinositol 3'kinase/AKT pathway in diffuse large B-cell lymphoma survival. Blood 108 4178-4186.

Uddin S, Ahmed M, Bavi P, El-Sayed R, Al-Sanea N, AbdulJabbar A, Ashari LH, Alhomoud S, Al-Dayel F, Hussain AR et al. $2008 a$ Bortezomib (Velcade) induces p27Kip1 expression through S-phase kinase protein 2 degradation in colorectal cancer. Cancer Research 68 3379-3388.

Uddin S, Hussain A, Ahmed M, Belgaumi A, Al-Dayel F, Ajarim D, Bavi P \& Al-Kuraya KS 2008b S-phase kinase protein 2 is an attractive therapeutic target in a subset of diffuse large B-cell lymphoma. Journal of Pathology 216 483-494.

Uddin S, Siraj AK, Al-Rasheed M, Ahmed M, Bu R, Myers JN, Al-Nuaim A, Al-Sobhi S, Al-Dayel F, Bavi P et al. 2008c Fatty acid synthase and AKT pathway signaling in a subset of papillary thyroid cancers. Journal of Clinical Endocrinology and Metabolism 93 4088-4097.

Zabeau L, Lavens D, Peelman F, Eyckerman S, Vandekerckhove J \& Tavernier J 2003 The ins and outs of leptin receptor activation. FEBS Letters 546 45-50.

Zimmermann-Belsing T, Brabant G, Holst JJ \& FeldtRasmussen U 2003 Circulating leptin and thyroid dysfunction. European Journal of Endocrinology 149 257-271. 